\title{
Cuba: Healthcare and the Revolution
}

\author{
LA Binns
}

\begin{abstract}
This paper depicts Cuba as a relic of the Cold War. Its coverage of healthcare demonstrates steadfastness and success in surmounting hurdles of complacency and disregard to socialized medicine - an extension of Soviet patronage and third world alliances. The literature relays a mission of inclusivity underpinned by political ideology and a conviction to humanity. With the aid of endorsements, it speaks to contrasts and critiques in service and results by reflecting on the delivery of free healthcare for all Cuban citizens and its impression on the eradication of numerous diseases, reduced mortality rate and increased life expectancy. Punished by the longest trade embargo in modern history, the regime is in possession of limited resources to expedite remedy to its subjects. Such, much to the dislike of the authorities, elevates elements of distinction in association with the dispensation of service and drugs demonstrated by an evolving two-tier system for the disenfranchised and privileged clientele while simultaneously impacting the maintenance of facilities and equipment. Consequently, it recognizes harsh ramifications attributed to compliance with ideology and subtle adjustments to withstand external exertion. The Cuban replica is currently a tale of sorts awaiting a comprehensible definition for future generations.
\end{abstract}

Keywords: Cuba, healthcare, Revolution

\section{Cuba: la Atención a la Salud y la Revolución}

\author{
LA Binns
}

\begin{abstract}
RESUMEN
Este trabajo describe a Cuba como una reliquia de la guerra fría. Su discusión en torno a la atención de la salud demuestra firmeza y éxito en la superación de los obstáculos provenientes de la autocomplacencia e indiferencia frente a la "medicina socializada" - una extensión del apoyo soviético y las alianzas del tercer mundo. La literatura transmite una misión de inclusión apuntalada por ideología política y una convicción de humanidad. Con documentación de apoyo, el trabajo se refiere a los contrastes y críticas del servicio y los resultados, reflexionando sobre los servicios de atención médica gratuita para todos los ciudadanos cubanos. Asimismo expone su impresión sobre la erradicación de numerosas enfermedades, la disminución de la tasa de mortalidad, y el aumento de la esperanza de vida. Castigado por el embargo comercial más largo de la historia moderna, el régimen se halla en posesión de limitados recursos para ofrecer soluciones a los ciudadanos. Para pesar de las autoridades, estas cosas aumentan los elementos de diferenciación asociados con el ofrecimiento de servicios y medicamentos, demostrada por un sistema que se va desarrollando en dos planos - los carentes de privilegios frente a una clientela privilegiada - en tanto que a su vez se hace sentir el impacto sobre el mantenimiento de las instalaciones y los equipos. Por consiguiente, el trabajo reconoce las duras ramificaciones que se atribuyen al cumplimiento con la ideología y los sutiles
\end{abstract}

From: Graduate School of Interdisciplinary Studies, The Union Institute and University, Cincinnati, Ohio, USA.
Correspondence: Dr L Binns, Graduate School of Interdisciplinary Studies, The Union Institute and University, 440 East McMillan, Cincinnati, Ohio 45206, USA. E-mail: labenz@dr.com 
ajustes para resistir la presión externa. El modelo cubano es actualmente una suerte de historia en espera de una definición comprensible para las generaciones futuras.

Palabras claves: Cuba, salud, Revolución

West Indian Med J 2013; 62 (3): 245

\section{INTRODUCTION}

The Cuban healthcare system has undergone a metamorphosis of considerable proportions subsequent to the transition of power from the Batista to Castro regime. The deposed Batista, who presided over an island most favourable to a small, wealthy ruling class, was oblivious to the concerns of a large impoverished social caste and therefore made provision for the elite in the form of privately owned facilities while ignoring the plight of the underclass who were relegated to 46 overcrowded and understaffed government hospitals.

Such disproportionate delivery of service and stark contradiction to a moral code of ethics was transposed by a change in government and ideology. The Castro administration proceeded to honour its revolutionary campaign promise to provide a government attentive to the interests of the disenfranchised and in compliance with socialist tenets. Hence, Cuban healthcare commenced on a new path. To redirect the emphasis from profit that exacerbated economic inequality and social injustice - as demonstrated by the existence of exclusive medical centres - and curtail poor hygiene, inefficient sanitation and malnutrition contributing to the infant mortality rate of 60 per 1000 lives, maternal mortality rate of 125.3 per 1000 , a general mortality rate of 6.4 per 1000 and life expectancy of 65.1 years, the new establishment adopted a constitution which classified healthcare as a right guaranteed to every citizen (1-3).

In allegiance with a philosophical conviction in conjunction with egalitarian ideals and the World Health Organization's (WHO) prerequisites, Havana adopted basic components in its attempt to fulfill a compulsion to the Cuban citizenry. With emphasis on medical effectiveness such as quantitative indicators incorporating infant mortality rate, nutritional status and life expectancy and social impact, a comprehensive plan of action began to take effect.

Despite vulnerability and international obstacles highlighted by the Bay of Pigs invasion and the United States (US) trade embargo in 1961, Cuba's unwavering revolutionary stance won the political and economic endorsement of the Soviet Union. This relationship, along with similar acknowledgement from the Eastern Bloc, was soon realized through the Ministry of Public Health's control of all healthcare facilities.

In the years ahead, the overhaul encompassed the integration of all private organizations with the intention of promoting outreach programmes and polyclinics alongside hospitals. A hierarchical structure was specifically introduced and priorities were realigned with a focus on wellness and prevention by forging the medical and residential communities. At its lowest strata are units comprised of family doctors charged with responsibilities for assigned neighbourhoods. In addition, these practitioners, who are equally distributed across the Cuban landscape, are also advocates of education and links to additional services if required.

The pursuit of excellence in medicine afforded a country of 11.5 million is worthy of international recognition. Within three decades, there is record of annual expenditure by Cuban estimates at $10-15 \%$ of GDP with results of over 60000 trained physicians, a national ratio of one to every 180 persons, scores of nurses, physical therapists and medical technicians, 267 hospitals, 440 clinics, 5000 medical and biological scientists, 11 research institutes inclusive of pharmaceutical and biological facilities and 15 medical schools (Table 1).

Table 1: Statistics on public health facilities and personnel, 1999-2004

\begin{tabular}{|c|c|c|c|}
\hline Public Health Service Statistics & $1999-2000$ & $2002-2003$ & 2004 \\
\hline Total doctors & 63483 & 66285 & 68155 \\
\hline Population per doctor & 175 & 169 & 165 \\
\hline Population per nurse & 132 & & \\
\hline $\begin{array}{l}\text { Population covered by family } \\
\text { doctor service }\end{array}$ & 98 & 99.1 & 99.1 \\
\hline Service & $(\%)$ & & \\
\hline Hospitals & 284 & 270 & 267 \\
\hline Polyclinics & 436 & 440 & 444 \\
\hline
\end{tabular}

Source: Ministry of Public Health, 2005

Further, the magnitude of success by third world standards is astounding (4-6). In recent years, the infant mortality rate has exceeded expectations at seven per 1000 births and is partly due to a comprehensive vaccination effort that combats 12 major diseases. Life expectancy is on average 77 years (Tables 2 and 3).

A microscopic overview of the system at work explains the magazine The Economist's complimentary feature toward the island's evolving regime. In its article "One thing Cuba does right", the remark: "Cuban medicine is disciplined and innovative.... Cuban research establishments have made breakthroughs in vaccines, immunology and biotechnology" (7) is a gesture in response to free and effective medical and healthcare that range from services in rural clinics and maternity homes to municipal hospitals, all of 
Table 2: Cuba in international perspective

\begin{tabular}{lcc}
\hline & $\begin{array}{c}\text { Infant mortality rate } \\
\text { per 1000 live births } \\
\mathbf{1 9 8 3}-\mathbf{1 9 8 8}\end{array}$ & $\begin{array}{c}\text { Per capita gross } \\
\text { domestic product in } \\
\mathbf{1 9 8 8} \text { (US\$) }\end{array}$ \\
\hline OECD & 9 & 17097 \\
Cuba & 15 & 2509 \\
Soviet Bloc & 22 & 2162 \\
Asia planned economies & 39 & 30 \\
Latin America and Caribbean & 54 & 2102 \\
Asia Pacific & 59 & 1559 \\
Middle East and North Africa & 71 & 1976 \\
South Asia & 102 & 319 \\
Sub-Sahara Africa & 109 & 319 \\
\hline
\end{tabular}

Source: The Economist: Book of Vital World Statistics. London: Random House; 1990.

OECD (Organization for Economic Cooperation and Development) comprises 25 industrialist capitalist countries of which Western Europe, Canada, the United States of America, Japan, Australia, New Zealand and Mexico are members.
(Figure). Cuba's distinction in medicine has gained commendation abroad due to the following achievements

* The role of sole producer of a vaccine against the bacteria that causes meningitis-B

* The creation of a micro-surgical approach to cure retinitis pigmentosa with an $80 \%$ success rate

* A successful treatment for vitiligo (loss of skin pigmentation) once beyond cure

* Aids research described as helpful

Moreover, with the likes of the Centro de Ingenieria Genetica y Biotecnologia (CIGB), Cuba has developed a large amount of drugs for local and international consumption - a contribution considered the island's sixth largest currency earner of \$120 million in 1995 (6-8).

Accolades are forthcoming from third world countries that are beneficiaries of the human resources made available by the ambassadorial spirit of the late Ernesto Che Guevara, a medical practitioner, national hero and central figure of the socialist revolution and the Cuban government. In the 1980s,

Table 3: Comparative health record

\begin{tabular}{lrrrrc}
\hline & Cuba & UK & Chile & Haiti & Guatemala \\
\hline Life expectancy (years; 1995-2000) & 76 & 77 & 75 & 52 & 64 \\
Life expectancy (year; 2001) & 77 & 77 & 76 & 49 & 65 \\
Doctors per 100 000 (1990-1999) & 530 & 164 & 110 & 8 & 93 \\
Doctors per 100 000 (1990-2002) & 590 & 274 & 115 & 25 & 90 \\
\hline
\end{tabular}

Source: UN Development Programme. Human Development Report; 2003.

which are supplemented by technologically advanced research centres.

Each urban neighbourhood is equipped with a community clinic that addresses the needs of its residents. In addition, an expansion of network links the extension of benefits from local clinics for minor ailments to regional hospitals for the chronically ill while providing the required service and medicines whenever available, free of charge

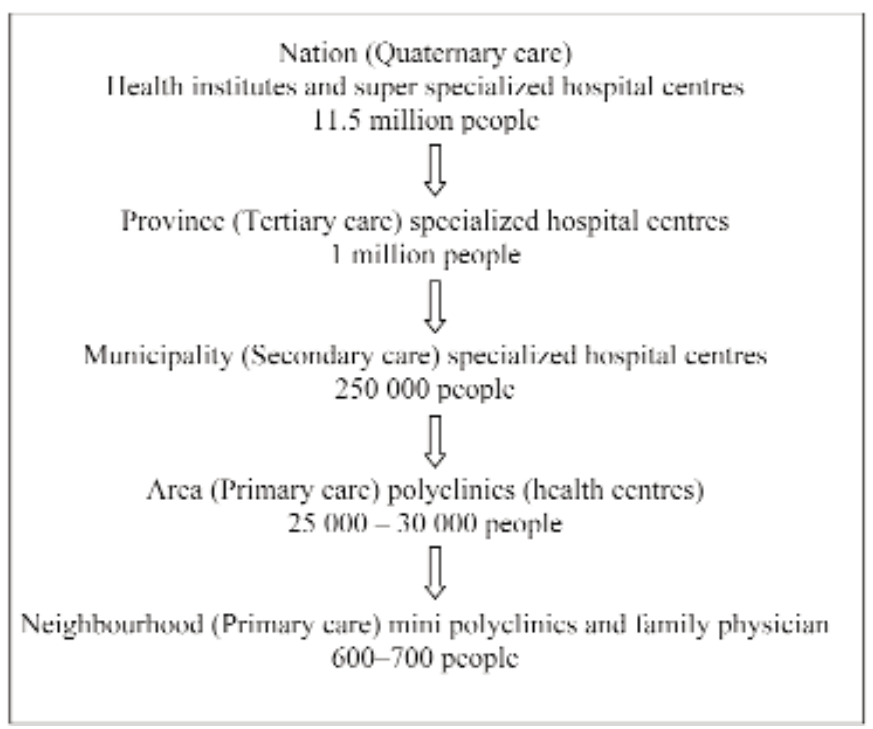

Figure: Cuba's integrated, hierarchical healthcare system.
2000-3000 Cuban physicians were deployed yearly overseas for 24-month rotations throughout Latin America, the Caribbean, Africa, the Middle East and Asia. Over a 30-year period, a list of partners is inclusive of but not limited to Jamaica, Nicaragua, Grenada, Guatemala, Guyana, Haiti, the Dominican Republic, Angola, Ghana, Mozambique, South Africa and the Ukraine - all recipients of Cuban doctors who were engaged to address natural disasters or an ongoing shortage of medical personnel.

An attempt by the Castro administration to globalize socialized medicine has also materialized in the form of a medical school in Havana in 1988 with the sole purpose of training potential candidates of the underdeveloped world to serve rural populations. To date, South Africa among others has utilized the opportunity to train students who are committed to return home and render a service to underprivileged societies $(3,9)$.

Amidst good intentions, a contrast nevertheless exists in all aspects of the island's healthcare provision. Unlike central Havana's Hospital Clinico Quirurgico "Hermanos Ameijeiras", a modern medical jewel for treatment in the field of bacteriology, microbiology, gastroenterology, ophthalmology, dermatology, neurology, oncology, pathology and trauma among others, most medical centres are comparable to Vedado's Hospital Calixto Garcia - old, unsatisfactorily designed and inadequately furnished to meet the demands of gravely ill and elderly patients. An observation 
of these facilities reveals beds in large and scantly maintained rooms void of privacy, overcrowded waiting rooms, limited technology and medical stock and sparsely functional laboratories. In addition, upon release from said establishments, the issuance of prescriptions in many instances becomes an exercise in futility largely due to a shortage of drugs at local pharmacies.

Adding to scarcity is the acknowledgement of a twotier configuration that caters to the elite. In spite of contradiction to the principles of the revolution and comprehensive healthcare, Cuba, in an effort to generate capital while simultaneously experimenting with "up to date" medical processes, grudgingly offers private hospitals providing specialized services to foreigners at a cost amounting to over \$24 million in 1995. Such hospitals include "state of the art" facilities.

The likes of Centro Internacional de Retinosis Pigmentaria "Camilo Cienfuegos", which is renowned for its treatment of retinitis pigmentosa and other eye diseases and additional centres, notably Cira Garcia, El Centro, La Pradera and Topes de Collantes concentrating in cancer treatment, skin diseases, open heart surgery, Parkinson's disease, kidney transplants and neurological disorders, fall within this
Rights, Washington's obstruction favours the Trading with the Enemy Act, the Cuban Democracy Act and the HelmBurton Act (Table 4).

An analysis of the effects is apparent as the island is confronted with an inadequacy of drugs due to an inability to purchase. This is reflected by a decrease in spending for medical imports from \$227 million in 1989 to \$74 million in 1994 and restrictions on medical products bearing US patents. In a published report entitled "Cuba: Health Care and the US Embargo," Peter Schwab, a political scientist at Purchase College, the State University of New York, purports that logistics and geopolitics are defining themes in Cuba's political and medical lexicon (6). Medicuba, a domestic outfit under obligation to procure medical supplies for local use spends $\$ 6$ million in air and freight fees for medicines and equipment that could be obtained on the US market for a mere fraction of the cost $-\$ 1$ million.

Ideological differences reflect varying dimensions to a destructive strategy. The US has threatened third parties (countries and foreign enterprises) with sanctions for failure to comply with the terms of the embargo. Illustrations include a retreat in 1995 by Merck, a US pharmaceutical manufacturing giant when faced with penalties for providing the Cuban government with medical information; comparable

Table 4: United States trade embargo

\begin{tabular}{lcc}
\hline Laws & Year Introduced & Impact \\
\hline Trading with the Enemy Act & 1917 & establishes a ban on trade \\
Cuban Democracy Act & $\begin{array}{c}\text { (enacted 1963) } \\
\text { Helms-Burton Act }\end{array}$ & tightens economic sanctions \\
\hline
\end{tabular}

category. According to the North American Congress on Latin America, by 1997 these exclusionary programmes, that to some detractors are reminiscent of the past, had treated 7000 foreigners from 60 different countries but contribute a small fraction $(30 \%)$ of their earnings to the public sector with the remaining portion used at the discretion of the private medical entities $(7,10)$.

With the sudden dismantling of the Soviet empire in 1989, the Cuban establishment has been struggling to counter surmounting challenges. These entail a loss of $85 \%$ of its international trade and subsidies to the tune of $\$ 5$ billion per annum - both contributors to increasing unemployment and inflation. Furthermore, a spiralling deficit ranging from 1.403 billion pesos in 1989 to 4.2 billion pesos in 1993, combined with a 41-year old US trade embargo valued beyond $\$ 41$ billion provide added cause for concern.

Without Soviet credits to offset the embargo, Havana is experiencing severe austerity. In disregard of the United Nations General Assembly's objection to the economic interdiction and Article 25 on Universal Declaration of Human action was embraced by Japan's Toshiba and Sweden's LKB regarding the sale of laboratory equipment to the Spanish island. Argentina's Medix also followed suit in rela-tion to a pending shipment of spare parts in light of severe punishment. The embargo also prohibits the importation of goods of Cuban origin from entry to US shores.

Unfortunately, the ramifications associated with such economic restrictions are disheartening. While the Cuban American National Foundation (CANF), a reactionary lobby group with roots in South Florida, contends that such does not deny medicine and medical supplies to the Cuban people, its claim that the Cuban Democracy Act - through approved license requests for US companies and subsidiaries - encourages the donation of humanitarian aid including medicine, food and clothing is questionable $(3,6,11)$.

The New England Journal of Medicine refutes that assertion by referring to stipulations as the immediate cause of an epidemic of 50000 cases of optic and peripheral neuropathy between 1991 and 1993 (12), whereas the American Journal of Public Health states "the embargo has contributed to the deterioration in the quality of healthcare and has 
exacerbated undernutrition by raising the cost of medical supplies and food to the island" (13). A recent disclosure by the Pan American Health Organization (PAHO) which referenced Cuba's shrinking healthcare allocation as being less in percentage of its annual budget to that of regional countries namely Jamaica, Costa Rica and the Dominican Republic is also testament to consequences attributed to US policy of disengagement $(3,11-13)$. The struggle to protect relevance is underscored by Havana's tenacity as well (Table 5). the scarcity of medicines that are often only available in hard currency retail stores is out of reach for average Cubans in need of medical remedy. Facilities are in need of updated modifications to maximize safety and service; many ageing water conduits require replacements to reduce energy consumption and prevent leaks and loss of water - the culprit for the breeding of mosquitoes such as Aedes aegypti that in turn spread dengue and yellow fever (10).

Table 5: Cuba's public health budget (in million pesos)

\begin{tabular}{ccccc}
\hline Year & Health budget & Per inhabitant & \% of GDP & \% of national budget \\
\hline 1990 & 1045.1 & 98.6 & 5.3 & 7.4 \\
1995 & 1221.9 & 111.3 & 5.8 & 8.8 \\
1998 & 1473.1 & 132.4 & 6.4 & 13.1 \\
\hline
\end{tabular}

Source: Ministry of Finance, Havana

Throughout the first decade of the $21^{\text {st }}$ century, evidence of scarce and diluted material, financial and human resources bear dire consequences that continue to multiply with challenges inclusive of an inability to reorganize the system particularly in relation to primary care, medical education, dilapidated hospitals and institutes and effective management and maintenance of associated facilities. These challenges affect a growing portion of the population that is susceptible to psychological stress, diabetes, obesity and other forms of illnesses linked to deteriorating political and economic factors (14).

Although infant and maternal mortality declined from $9.9 \%$ to $4.7 \%$ per 1000 between 1993 and 2008 and from $65.7 \%$ to $31.1 \%$ per 1000 between 1993 and 2006, respectively, the glory days of socialized medicine is under severe threat. Reports indicate that maternal mortality rate has increased to $46.5 \%$ in 2008 and $53 \%$ in 2009 . The ratio of hospital beds per 1000 inhabitants decreased as well from $6 \%$ to $4.6 \%$ between 1993 and 2008 and though the ratio of physicians per 1000 rose from $46.7 \%$ to $66.3 \%$ during the same time, an estimated $35 \%$ to $48 \%$ of all Cuban doctors work overseas, particularly in Venezuela or have changed vocation for better wages (Table 6).

This reality contributes to a shortage of medical personnel and therefore limited access to services. In addition,
During a twenty-year period commencing in 1989, Cuba made significant strides regionally by reducing five morbidity rates, specifically venereal diseases, yet, in 2009 when the healthcare budget was decreased by $8 \%$, in current pesos, morbidity from food poisoning, tuberculosis and acute respiratory infection showed a rise. There is also heightened concern regarding the presence of dengue fever, haemorrhagic conjunctivitis and leptospirosis and a decline in immunization in relation to triple DPT (diphtheria, pertussis, tetanus) vaccine and tuberculosis $(14,15)$ [Table 7].

Shy of the removal of an outdated and ineffective blockade, seemingly scared but unbeaten options abound. In a highly publicized letter, Dr Cesar Chelala, a New York based physician, recommended a dialogue conducted by a commission of notable medical professionals and facilitators (eg PAHO) agreed to by both governments with the intent of evaluating the island's capability to offer healthcare and negotiate the impartial channelling of required goods and services to a people in need (16). The idea has been ridiculed by some medical practitioners. Dr G Martin, a practising physician in Kansas City, and his colleague Dr Enrique Huertas, a prominent member of the Cuban Medical Association in Exile are of the opinion that it is ill conceived (16). However, considering its unbiased orientation, it deserves

Table 6: Social indicators: health

\begin{tabular}{lrrrrc}
\hline & $\mathbf{1 9 8 9}$ & $\mathbf{1 9 9 2 / 5}$ & $\mathbf{2 0 0 6 / 7}$ & $\mathbf{2 0 0 8}$ & $\mathbf{0 8 / 8 9}(\mathbf{\%})$ \\
\hline Infant mortality (per 1000) & 11.1 & 9.9 & 5.3 & 4.7 & -57 \\
Maternal mortality (per 1000) & 29.2 & 65.7 & 31.1 & 46.5 & 59 \\
Hospital beds (per 1000) & 6.0 & 6.0 & 4.8 & 4.6 & -23 \\
Physicians (per 1000) & 33.1 & 46.7 & 64.0 & 66.3 & 100 \\
\hline
\end{tabular}

Source: (15)

Cuba's infant mortality rate is second only to Canada within the hemisphere. 
Table 7: Social indicators: health

\begin{tabular}{lllllc}
\hline (\%) & $\mathbf{1 9 8 9}$ & $\mathbf{1 9 9 2 / 5}$ & $\mathbf{2 0 0 6 / 7}$ & $\mathbf{2 0 0 8}$ & $\mathbf{0 8 / 8 9}(\mathbf{\% )}$ \\
\hline Morbidity rates (per 1000) & & & & & \\
Acute respiratory & 36804 & 45021 & 43222 & 44236 & 20 \\
Acute diarrhoea & 8842 & 10380 & 6159 & 6132 & -30 \\
Chicken pox & 365 & 1138 & 316 & 173 & -53 \\
Food poisoning & na & 87 & 196 & 196 & 125 \\
Gonorrhoea & 381 & 412 & 42 & 36 & -90 \\
Hepatitis & 106 & 295 & 87 & 43 & -59 \\
Syphilis & 82 & 143 & 16 & 14 & -83 \\
Tuberculosis & 5 & 14 & 7 & 7 & 40 \\
& & & & & \\
Immunized population (1000s) & 157 & 164 & 112 & 121 & -23 \\
Double & 354 & 510 & 133 & 116 & -67 \\
Triple (DPT) & 320 & 149 & 112 & 121 & -62 \\
Tuberculosis & & & & & \\
\hline
\end{tabular}

Source: (15)

consideration in good faith at a critical juncture of protracted global recession when the well-being of the Cuban populace is at stake.

In summary, a solution must transcend polemics from Washington, DC and embrace a conveyance of goodwill which could demolish an archaic political stalemate by reinforcing a long awaited dialogue and subsequent crisis intervention. This bold precedent could therefore serve as a precursor to collaboration in business ventures and ultimately diplomacy.

\section{REFERENCES}

1. Roemer M. Healthcare systems in world perspective. Ann Arbor: Health Administration Press; 1976.

2. Gilpin M. Cuba on the road to a family medicine nation. Fam Med 1989; 21: 405-7, 462, 464.

3. Nayeri K. The Cuban health care system and factors currently undermining it. J Comm Health 1995; 20: 321-34.

4. Iatridis D. Cuba's health care policy: prevention and active community participation. Social Work 1990; 95: 29-34.

5. Dale R. Integrating natural and traditional medicine with conventional medicine in Cuba. Cuba Update; 1997.
6. Schwab P. Cuba: health care and the US Embargo. Monthly Review 1994; 49: 15-25.

7. One Thing Cuba does right. (Cuba is gaining an international reputation for its medical-treatment facilities and is attracting patients from around the world) (Brief Article). The Economist; September 7, 1996: 42.

8. A conversation with Michele Frank MD. Cuba, 1998. Update; 1997.

9. USA-Cuba InfoMed. Health news from Cuba, 1998. Havana/Cuban interest section. 1998 Dec 18. Available from: http://www. cubasolidarity.net/ hnews1998.html

10. Schechner R. Cuba: lift the embargo now. The Drama Review (TDR) 1994; 38: 7-10.

11. Murray M. Cruel and unusual punishment: the blockade against Cuba. New York: Ocean Press; 1993.

12. Eisenberg L. The sleep of reason produces monsters - human cost of economic sanctions. New Engl J Med 1997; 336: 1248-50.

13. Garfield R, Santana S. The impact of the economic crisis and the US embargo on health in Cuba. Am J Public Health 1997; 87: 15-20.

14. Haddad J. International workshop on epidemic neuropathy in Cuba: report summary. MEDICC Review 2005; 7: 27-30.

15. Mesa-Lago C, Vidal-Alejandro P. The impact of the global crisis on Cuba's economy and social welfare. J Lat Amer Stud 2010; 42: 689717.

16. Chelala C. Relations between the US and Cuba: a proposal for action. JAMA 1996; 275: 559-60. 